\title{
36
}

\section{TOPP - A METHOD FOR COMPANY SELF ASSESSMENT}

\author{
Knut S Stokland \\ SINTEF Production Engineering, N-7034 Trondheim, Norway
}

\section{TOPP SELF ASSESSMENT (TSA)}

This handbook has been written by NTH/SINTEF on the authority of TOPP. The TOPP program offers several methods and tools for productivity measurement; TOPP Self Audit, Extended audit and Benchmarking; Handbook in TOPP Self Assessment (TSA) is a supplement to these tools.

The TSA system was developed to meet the needs in industry for measurement and evaluation of results of the business processes in the company. Identification of the business processes is a central part of designing the company's assessment plans. Understanding of these processes will be the basis in management of manufacturing enterprises in the future, and measuring and assessment are thus important tools for the company management.

Business processes represent the conversion of resources, capital, materials and manpower into internal or external products through a set of activities.

TSA focuses on productivity and on the companies performing the assessment themselves. Comparisons to other companies or any other defined reference are not of primary interest. TSA should provide trends that show how the results from selected business processes progress over time.

TSA should be a tool for continuous improvements of the business processes. The target groups for TSA are all manufacturing enterprises in the technological industry including the electronics/computer industry, the textile/clothing and woodware industry. The TSA primarily addresses the top management of the company, but every employee will benefit from the information procured by TSA.

Participation in the TOPP programme is not a requirement for utilizing the TSA.

The handbook makes suggestions as to what may be analyzed (analyzing areas and indicators) of the business processes, and how (measurement techniques) these areas may be analyzed. TSA is a management tool for evaluation of the most important business processes. All processes given in the handbook are not supposed to be part of every evaluation system in each company. 
The TSA handbook is consistently avoiding the terms "revision" and "audit", thus taking the focus away from comparisons with a defined reference or standard.

The handbook is tentatively giving a step by step plan for designing and accomplishing self assessment in a company.

\section{THE TSA CONCEPT}

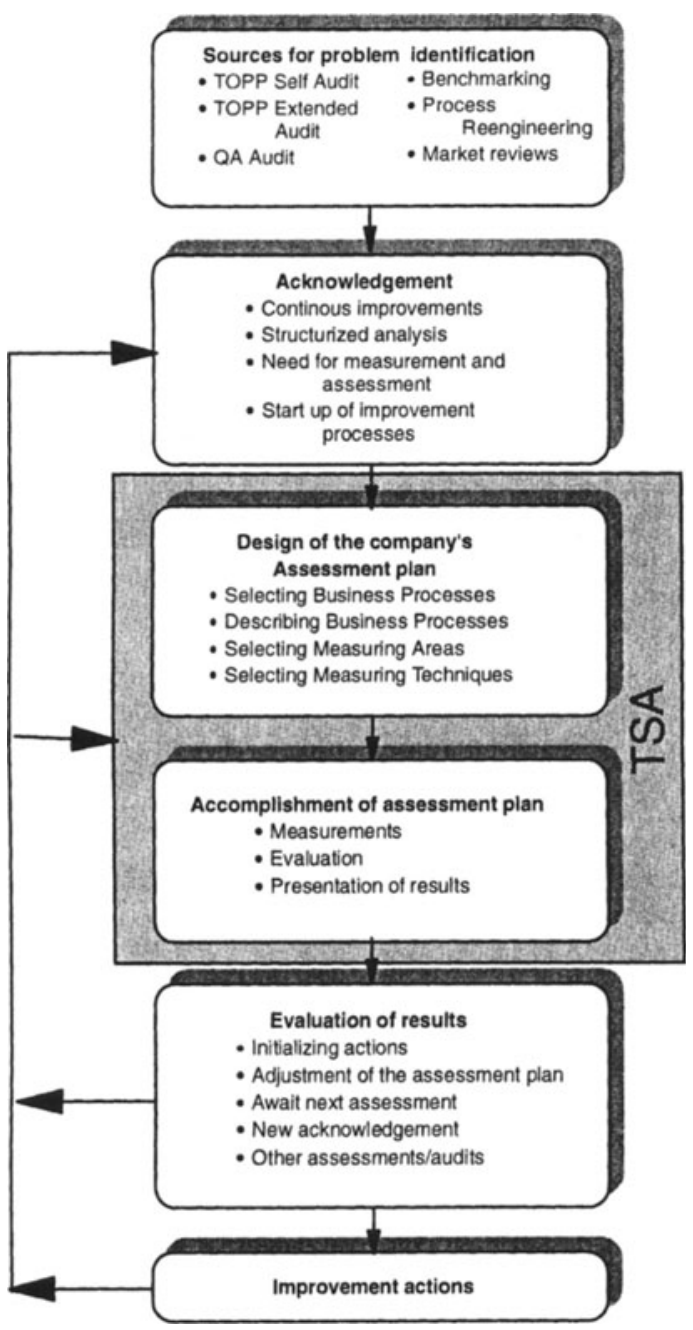

Figure 1 The TSA Concept

TOPP Self Assessment is a tool to support the management in increasing the productivity and the competitiveness of the company. The tool is not trade dependent, and it is meant to be 
supportive in designing and accomplishing the company's assessment plans. It is based upon measuring the results of own work on a higher level over time. Through repeated measurements a set of data showing trends is built up. The data is presented in an assessment report, adjusted to the different decision levels in the company. Hiring external expertise for design and accomplishment of the assessment plans is not necessary.

\section{DESIGN OF THE COMPANY'S ASSESSMENT PLAN}

Design of the company's assessment plan consists of:

- selecting business processes

- accomplishment of the assessment plan

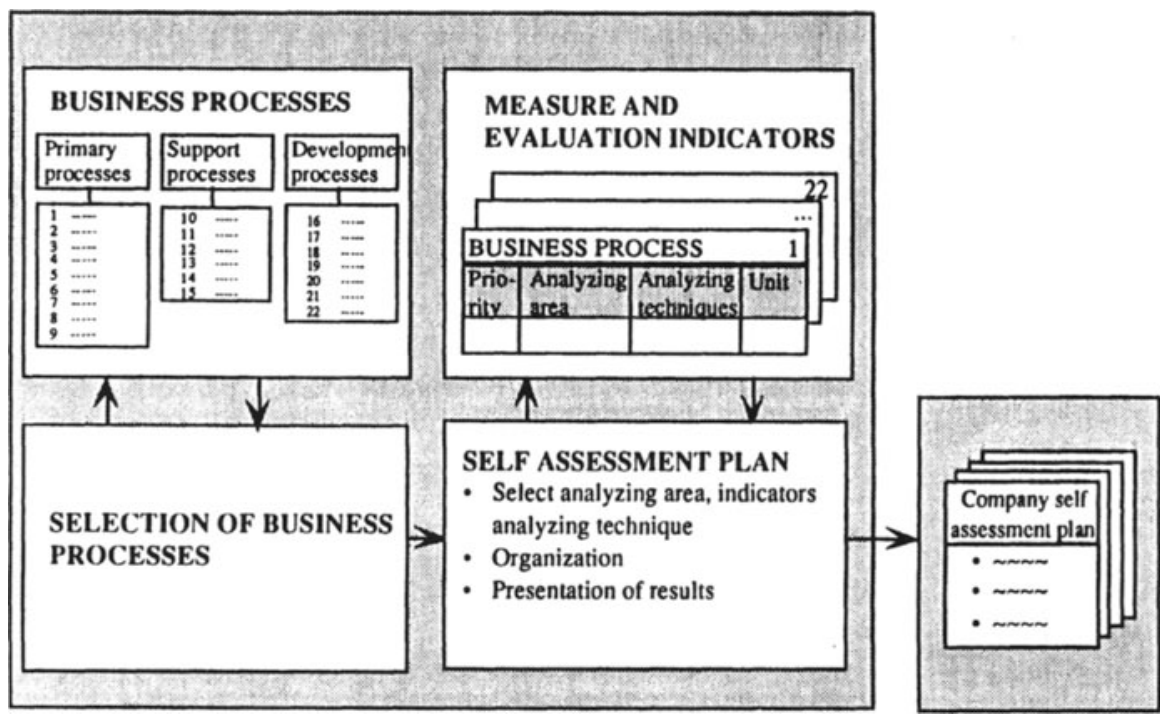

Figure 2 Procedure for designing a company self assessment plan

Business processes are selected acknowledging the need for performing a self assessment.The company's top management makes the selection. In TSA a set of "standard business processes" is available. 

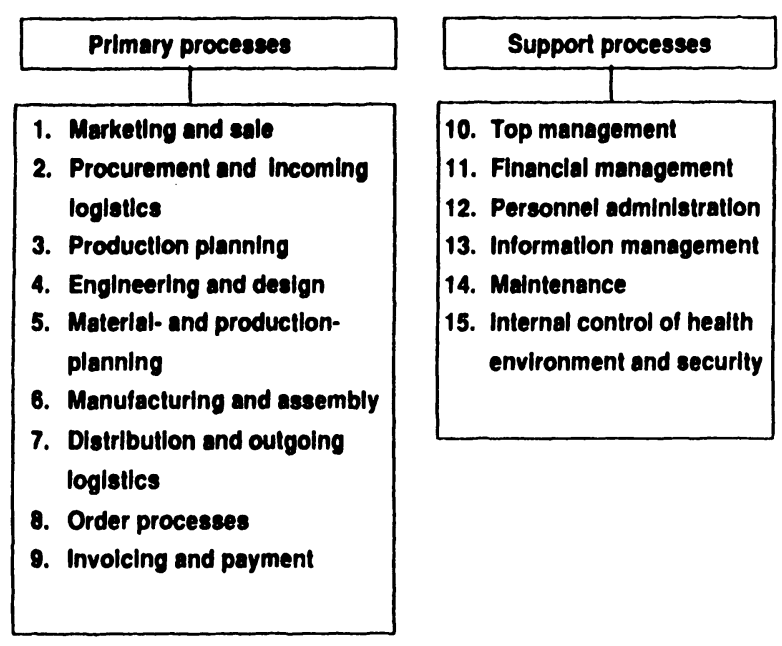

\section{Development processes}

16. Continouos improvement and change

17. Market development

18. Product development

19. Production engineering development

20. Personnel development

21. Suppller development

22. Development of external relations

Figure 3 Standard business processes, Mechanical industry

The assessment plan consists of a set of assessment documents in which each measuring area and each measuring technique is described. The assessment team is chosen, and the handling and presentation of the results is decided upon.

The TSA handbook offers a lot of analyzing areas, each one with indicators and measuring techniques. The company has to select what is suitable, convenient for them to analyze and measure. Example of such analyzing areas, indicators and measuring techniques are given in the following figure. 


\begin{tabular}{|c|c|c|c|}
\hline \\
\hline PROCURE & MENT AND INCOMIN & G LOGISTICS & Page 1 of 2 \\
\hline \multicolumn{4}{|c|}{$\begin{array}{l}\text { By procurement and incoming logistics we mean all activities concerning the } \\
\text { obtainment of raw material. }\end{array}$} \\
\hline nioplit & 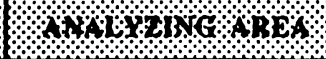 & 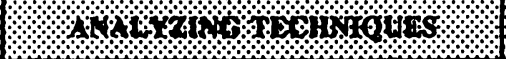 & $+4+2$ \\
\hline 1 & $\begin{array}{l}\text { Stock } \\
\text { Turnover }\end{array}$ & $\begin{array}{l}\text { Measure the turnover in stock of raw } \\
\text { materials }\end{array}$ & \\
\hline 1 & - Total value & $\begin{array}{l}\text { Measure the total value of raw } \\
\text { materials }\end{array}$ & NOK \\
\hline 2 & - Scrap & $\begin{array}{l}\text { Measure the share of scrap in stock of } \\
\text { raw materials }\end{array}$ & NOK, \% \\
\hline 2 & - Response time & $\begin{array}{l}\text { Measure the time from confirmation } \\
\text { of onder to delivery }\end{array}$ & Time \\
\hline 1 & $\begin{array}{l}\text { Security of delivery } \\
\text { - Share of too late } \\
\text { deliveries }\end{array}$ & - Make a system to registrate arrival & $\%$ \\
\hline 2 & $\begin{array}{l}\text { Volume (NOK) of too } \\
\text { late deliveries }\end{array}$ & $\begin{array}{l}\text { Measure the value and number of too } \\
\text { late deliveries }\end{array}$ & $\begin{array}{l}\text { NOK, } \\
\text { ime }\end{array}$ \\
\hline 2 & - Accumulated delays & $\begin{array}{l}\text { Measure and accumulate too late } \\
\text { deliveries }\end{array}$ & Time \\
\hline 2 & $\begin{array}{l}\text { Deviation by delivery } \\
\text { - Number of deficiencies } \\
\text { pr delivery }\end{array}$ & - Measure and group & Number \\
\hline 2 & The consequence & $\begin{array}{l}\text { Measure the consequence of deviation } \\
\text { in delivery - time/cost }\end{array}$ & $\begin{array}{l}\text { Time, } \\
\text { NOK }\end{array}$ \\
\hline 2 & $\begin{array}{l}\text { Volume } \\
\text { - Volume of purchase } \\
\end{array}$ & Volume of categorized purchases & NOK \\
\hline 1 & $\begin{array}{l}\text { Resources } \\
\text { - Man-hours }\end{array}$ & $\begin{array}{l}\text { Share of total man-hours spent on the } \\
\text { process }\end{array}$ & $\%$ \\
\hline 1 & - Value & $\begin{array}{l}\text { Value of purchased goods compared } \\
\text { to total sales }\end{array}$ & $\%$ \\
\hline 2 & - Persons involved & $\begin{array}{l}\text { Percent of the working staff involved } \\
\text { in the process }\end{array}$ & $\%$ \\
\hline
\end{tabular}

Figure 4 Example of analyzing areas, indicator and analyzing techniques 


\section{ACCOMPLISHMENT OF SELF ASSESSMENT}

The accomplishment of Self Assessment consists of the following main activities:

- collecting, arranging, sorting and editing of data

- report

When the assessment plan is worked out and the assessment team is chosen, the assessment may start with collecting and arranging/sorting the data.

OBTAIN INFORMATION

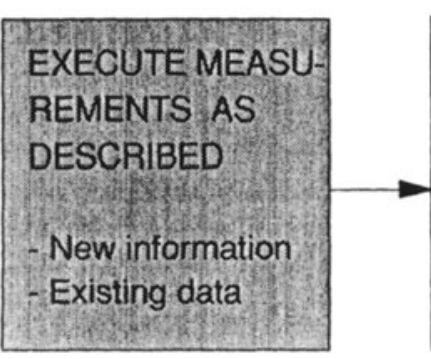

EVALUATION

COLLECTING, ARRANGING, SORTING AND EDITING DATA
REPORT

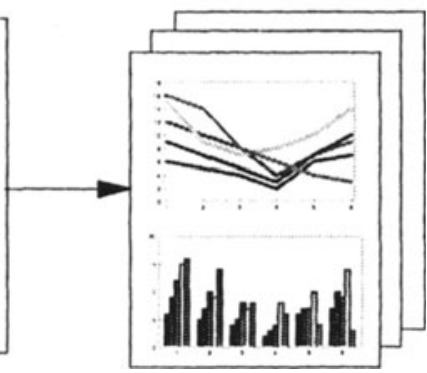

Figure 5 Accomplishment of Self Assessment 